\title{
Detection of Bovine Leukemia Virus Proviral DNA in Individual Cells
}

\author{
Michael L. Mirsky, ${ }^{1}$ Yang $\mathrm{Da}^{2}{ }^{2}$ and Harris A. Lewin ${ }^{2}$
}

\begin{abstract}
${ }^{1}$ Department of Veterinary Pathobiology; ${ }^{2}$ Laboratory of Immunogenetics, Department of Animal Sciences, University of Illinois at Urbana-Champaign, 210 Plant \& Animal Biotechnology Laboratory, Urbana, Illinois 61801
\end{abstract}

\begin{abstract}
We have developed a method of analyzing individual cells to detect proviral DNA of the bovine leukemia virus (BLV) using flow cytometry and PCR. Individual cells of the BL3* cell line, which contain multiple integrated copies of the BLV provirus, and the uninfected cell line $B L 3^{\circ}$, were sorted into wells of a 96-well plate. Following cell lysis, portions of the BLV envelope (ENV) and cellular prolactin (PRL) genes were amplified simultaneously using PCR. Viral and cellular products of first-round PCR were amplifled separately in a second round of PCR using "heminested" primers. Separation of the PCR products by polyacrylamide gel electrophoresis yielded distinct fragments of the predicted sizes. The operational sensitivity of this method for the detection of virus was $>90 \%$ when testing single infected cells. In addition, we were able to rellably amplify DNA from a single BL3* cell among as many as $10^{5} \mathrm{BL3}^{\circ}$ cells and established that the sensitivity for detecting a single infected cell among 20, 100, or 1000 uninfected cells was at least $90 \%$. Estimates of low percentages of infected cells were obtained by applying probability theory to results of experiments conducted on wells containing more than one cell. Using these methods, B lymphocytes obtained from the peripheral blood of BLV-infected cattle were tested for proviral DNA. BLV ENV was identified in $76.9 \pm 4.9 \%$ of single B cells tested from a seropositive animal with persistent lymphocytosis (PL), but in only $0.033 \pm$ $0.009 \%$ of $B$ cells from another seropositive cow without PL. This method of analyzing individual or small num-
\end{abstract}

bers of cells for the presence of specific DNA sequences provides a sensitive and quantitative tool for the study of the pathogenesis of infectious, neoplastic, and hereditary diseases at the single-cell level.

$S$ retroviral infection, such as serology, tisretroviral infection, such as serology, tis sue and cell culture assays, electron microscopy, and nucleic acid hybridization, have generally lacked the sensitivity desired for the very early identification of infection and associated progression to disease. ${ }^{(1)}$ With the development of PCR, ${ }^{(2,3)}$ it became possible to detect small quantities of viral DNA present among large numbers of cells. ${ }^{(4-8)}$ Because of its great sensitivity, PCR has been applied to the study of retroviral disease pathogenesis and estimation of the quantity of both cell-free and cell-associated virus. ${ }^{(9-12)}$ Quantitation of cells containing virus has been performed by comparing amplification products from test samples with (1) products of PCRs from serially diluted cells known to harbor a single copy of provirus, ${ }^{(9)}$ (2) PCR products obtained from limiting dilution of a plasmid containing virus, ${ }^{(10)}$ and (3) comparison against standard curves generated by amplification of controlled quantities of DNA from plasmids ${ }^{(11)}$ or cells ${ }^{(12)}$ containing virus. Some of the drawbacks to these methods include the need to isolate DNA from large numbers of cells, uncertainty as to the identity of specific cells containing viral DNA, reliance on limiting dilution and standard curves, and the use of radioisotopes to label the amplified products.
Our laboratory is investigating the immunogenetic basis of disease pathogenesis associated with bovine leukemia virus (BLV) infection. BLV is an exogenous retrovirus infecting cattle and sheep, which is related to the human T-cell leukemia viruses (HTLVs). ${ }^{(13)}$ Unlike the HTLVs, the primary cellular target of BLV is the B lymphocyte. ${ }^{(14,15)}$ In some animals, BLV infection progresses to the development of persistent lymphocytosis (PL), a polyclonal expansion of infected B cells, with a smaller number of animals developing mono- or oligoclonal lymphoid neoplasia. ${ }^{(16)}$ In this paper we describe a modified method of single-cell analysis ${ }^{(17,18)}$ that employs flow cytometry and PCR to directly test individual or multiple cells for the presence or absence of BLV DNA. Our ultimate goal is to use this method to quantitate the number of cells containing provirus in cattle infected with BLV. Determination of the peripheral blood concentration of BLV-infected leukocyte subpopulations in cattle with resistant and susceptible genotypes will permit us to distinguish whether resistant animals are able to control the spread of BLV infection in vivo. This method provides an alternative to other techniques used to identify and quantitate retrovirus-infected cells and may have applications in other areas of research in which the presence of specific infectious agents or genomic sequences in individual cells is pertinent to the development or expression of disease.

\section{MATERIALS AND METHODS Cell Lines}

The bovine lymphoblastoid cell lines $\mathrm{BL}^{*}$ and $\mathrm{BL}^{\mathrm{O}(19)}$ were maintained as described previously and used to es- 
tablish the optimal conditions for the simultaneous amplification of both cellular and viral templates. BL3* is productively infected with $\mathrm{BLV}$, and $\mathrm{BL} 3^{\circ}$ is the uninfected parental cell line.

\section{Animals \\ Holstein-Friesian cattle maintained as part of the research herd at the Uni- versity of Illinois were bled annually; leukocyte counts and differentials were evaluated by standard hematological techniques. ${ }^{(20)}$ Sera were tested for pre- cipitating antibodies to viral envelope and core proteins by agar gel immunod- iffusion using a commercially prepared antigen (Pitman-Moore, Atlanta, GA) ac- cording to the manufacturer's instruc- tions. The prevalence of BLV infection in this heard is $\sim 75 \%$. ${ }^{(20)}$ The diagnosis of lymphocytosis was based on the Euro- pean Community's Leukosis Key, ${ }^{(21)}$ and classification as PL was made only if an animal was lymphocytotic upon two consecutive bleedings, at least 3 months apart. Animals were selected on the basis of BLV infection and the presence $\left(\mathrm{PL}^{+}\right)$ or absence $\left(\mathrm{PL}^{-}\right)$of $\mathrm{PL}$.}

\section{Cell Separation and Flow Sorting}

Cultured cells were pelleted and washed three times in ice-cold phosphate-buffered saline (PBS). Cells were resuspended in PBS, counted on a hemacytometer, and adjusted to $2 \times 10^{6}$ cells $/ \mathrm{ml}$. Cells $\left(1 \times 10^{6}\right)$ were aliquoted into $0.75-\mathrm{ml}$ microcentrifuge tubes (Robbins Scientific, Sunnyvale, CA) and held on ice until cell sorting. For single-cell analysis, a laser-based flow cytometer equipped with a single-cell deposition device (EPICS 751 with Autoclone, Coulter Electronics, Hialeah, FL) was used to sort single cells into wells of a 96-well microtiter plate (Falcon 3911, Becton-Dickinson, Oxnard, CA), each containing $5 \mu \mathrm{l}$ of lysis solution ( $200 \mathrm{~mm} \mathrm{KOH}, 50 \mathrm{~mm}$ dithiothreitol). Cells were sorted on the basis of $\log$ green fluorescence and $90^{\circ}$ light scatter. Each plate included two wells containing 20 cells (positive control), two wells containing no $(0)$ cells (negative control), and the remainder were programed to receive 1 cell each. Before distributing cells into plates, fixed cells or beads stained with propidium iodide were sorted individually or in groups of 10 onto glass slides that were examined to ensure that the appropriate numbers of fluorescent particles were present in each droplet. After sorting, the plates were incubated at $65^{\circ} \mathrm{C}$ for $15 \mathrm{~min}$ in a 96-well thermal cycler (M J Research, Watertown, MA). Immediately after removing the plate from the thermal cycler, the reactions were neutralized with $5 \mu \mathrm{l}$ of $900 \mathrm{~mm}$ Tris- $\mathrm{HCl}, 300 \mathrm{~mm} \mathrm{KCl}$, and $200 \mathrm{~mm} \mathrm{HCl}$ and stored at $-20^{\circ} \mathrm{C}$ until used.

In experiments to determine sensitivity and reproducibility, target sequences were amplified in wells containing a single sorted BL3* and varying numbers of sorted $(10,100,1000)$ or manually diluted and distributed $\left(10^{4}, 10^{5}, 10^{6}\right) \mathrm{BL} 3^{\circ}$ cells. Manual distribution of larger numbers of $B L 3^{\circ}$ cells was required because of limitations imposed by reaction and well volume. $B L 3^{\circ}$ cells were pelleted, lysed, and neutralized in $1.5-\mathrm{ml}$ microcentrifuge tubes as outlined above. Lysates were added with other PCR reagents at the appropriate concentrations (described below) to wells containing a single previously sorted BL3* cell, and amplification was performed in a final volume of $100 \mu \mathrm{l}$.

BLV-infected animals were bled by venipuncture of the coccygeal vein. Blood was collected in acid-citrate dextrose and maintained on ice before cell isolation. The buffy coat was harvested after centrifugation for $10 \mathrm{~min}$ at $600 \mathrm{~g}$, diluted in serum-free L-15 medium, and layered over Histopaque (specific gravity 1.077; Sigma, St. Louis, MO). Peripheral blood mononuclear cells were harvested from the Histopaque-medium interface, washed three times in ice-cold PBS, and adjusted to a final concentration of $2 \times 10^{6}$ cells $/ \mathrm{ml}$ as described above. B cells were directly labeled by incubating aliquots of $1 \times 10^{6}$ cells with FITC-conjugated $F\left(a b^{\prime}\right)_{2}$ rabbit anti-bovine IgG (heavy and light chains-specific; Cappel,
Malvern, PA) for $30 \mathrm{~min}$ in the dark. Following staining, cells were washed three times in PBS and maintained in the dark on ice until cell sorting.

\section{Amplification of BLV and Cellular Prolactin Sequences}

Two separate rounds of PCR were performed for each sample using the oligonucleotide primers (Operon Technologies, Alameda, CA) listed in Table 1. Primers used for the amplification of PRL have been described previously. ${ }^{(18)}$ Primers for detecting the BLV envelope (ENV) gene were designed on the basis of published genomic sequences. ${ }^{(13,22-24)}$ In the first PCR, a complete potassiumfree PCR mixture was added to each well providing a final concentration of $50 \mathrm{~mm}$ $\mathrm{KCl}, 100 \mathrm{~mm}$ Tris- $\mathrm{HCl}, 2.5 \mathrm{~mm} \mathrm{MgCl}_{2}$, $100 \mu \mathrm{M}$ each dNTP (U.S. Biochemical, Cleveland, $\mathrm{OH}), 1$ unit of Taq polymerase (Perkin-Elmer Cetus), $0.2 \mu \mathrm{M}$ of each prolactin (PRL) primer, and $0.4 \mu \mathrm{M}$ of each BLV ENV primer in a final reaction volume of $50 \mu$ l, except as otherwise noted above. To establish optimum reaction conditions for detection of small numbers of viral sequences, DNA was isolated from cell lines using the protocol of Miller et al. ${ }^{(25)}$ and diluted with sterile $\mathrm{ddH}_{2} \mathrm{O}$ to concentrations ranging from 0.0005 to $5 \mathrm{ng} / \mu \mathrm{l}$. Two microliters of DNA dilutions $(0.001,0.01,0.1,1.0$, or $10 \mathrm{ng}$ ) was added to wells after other reagents had been aliquoted. The cycling parameters used in the first PCR were 3 min at $92^{\circ} \mathrm{C} ; 10$ cycles of $1 \mathrm{~min}$ at $92^{\circ} \mathrm{C}$, $3 \mathrm{~min}$ at $57^{\circ} \mathrm{C}, 1 \mathrm{~min}$ at $72^{\circ} \mathrm{C} ; 30$ cycles of $1 \mathrm{~min}$ at $92^{\circ} \mathrm{C}, 2 \mathrm{~min}$ at $57^{\circ} \mathrm{C}, 1 \mathrm{~min}$ at $72^{\circ} \mathrm{C}$; and $4 \mathrm{~min}$ at $72^{\circ} \mathrm{C}$. Following this thermal cycling program, $2 \mu \mathrm{l}$ of the first-round PCR-product was added to each of two second-round amplification mixtures containing $50 \mathrm{mM} \mathrm{KCl}, 10 \mathrm{~mm}$

TABLE 1 Oligonucleotide Primers Used for the Amplification of PRL and BLV ENV Sequences

\begin{tabular}{llllcc}
\hline Number & Primer & Locus & Primer sequence $\left(5^{\prime} \rightarrow 3^{\prime}\right)$ & Position $^{\mathrm{a}}$ & $\begin{array}{c}\text { Fragment } \\
\text { length (bp) }\end{array}$ \\
\hline 1 & HL033 & PRL & CGAGTCCTTATGAGCTTGATTCTT & $233-257$ & - \\
2 & HL034 & PRL & CTGGCCAAATATCATCTCCATGCC & $387-409$ & $1+2=177$ \\
3 & HL035 & PRL & GCCTTCCAGAAGTCGTTTGTTTC & $367-390$ & $1+3=156$ \\
4 & HL058 & ENV & CTGAAAGCCTTCAAATGCC & $4807-4825$ & - \\
5 & HL059 & ENV & TGAGCCTCTAGTATTTGGTC & $4998-5017$ & $4+5=210$ \\
6 & HL060 & ENV & ACAGGGAGCATCTCCAAGT & $4917-4935$ & $4+6=128$ \\
\hline
\end{tabular}

${ }^{a}$ Base designations are those of Sasavage et al. ${ }^{(38)}$, for PRL, and Sagata et al. ${ }^{(13)}$, for BLV ENV. 

dNTP, 1 unit of Taq DNA polymerase, and $0.2 \mu \mathrm{M}$ of each PRL or BLV ENV primer in a final volume of $50 \mu \mathrm{l}$. The use of primer "heminesting"(17) in the second round of PCR optimized the yield of the desired target while minimizing the production of nonspecific products that may have been generated during the less stringent first round of amplification. The cycling parameters used in the second PCR were 30 cycles of $1 \mathrm{~min}$ at $92^{\circ} \mathrm{C}, 30 \mathrm{sec}$ at $60^{\circ} \mathrm{C}$; and $5 \mathrm{~min}$ at $72^{\circ} \mathrm{C}$.

The PRL and BLV ENV products of the second-round PCRs from each well were combined and run in $6 \%$ polyacrylamide minigels (Hoefer Scientific Instruments, San Francisco, CA). The viral envelope target sequence was selected to contain a HaelII restriction site to confirm the specificity of the PCR product. Restriction enzyme digestion was performed using 5 units of HaelII (GIBCO BRL, Gaithersburg, MD) and $10 \mu l$ of the second-round PCR product in a final volume of $15 \mu l$.

\section{Statistical Analysis}

The operational sensitivity, a measure of the efficiency of amplification on a sample basis, was defined as the percentage of wells containing PRL $\left(\mathrm{PRL}^{+}\right)$, which also contained BLV ENV $\left(\mathrm{ENV}^{+}\right) \mathrm{PCR}$ products in reactions starting with a single $B L 3^{*}$ cell. Wells negative for PRL were not included in this calculation because it could not be determined
Tris- $\mathrm{HCl}, 2.5 \mathrm{~mm} \mathrm{MgCl}_{2}, 100 \mu \mathrm{M}$ each

whether the lack of amplified product was caused by the absence of a cell or by failure of amplification. Formulas to estimate the percentage of infected cells are based on the probability of observing a positive reaction and the true percentage of infected cells. A binomial distribution is assumed for the number of infected cells in a well and for the number of positive reactions among wells being tested. Adjustments for contamination were not considered necessary because preliminary data obtained by testing 30 wells without cells or DNA showed no evidence of contamination.

The maximum likelihood estimate for the probability that a well will have a positive reaction for BLV ENV is given by $\hat{w}=s / t$, where $s=$ number of wells with a positive reaction for PRL and/or BLV ENV, and $t=$ total number of wells positive for PRL. The probability of a well being positive for BLV ENV is a function of the percentage of infected cells and the operational sensitivity. A positive well is assumed to be due to the presence of at least one infected cell and the detection of at least one infected cell. Let $w=$ probability that a well is positive, $c_{i}=$ the probability that an infected cell will be detected when $i$ infected cells are present, and $b_{i}=$ the probability that a well will contain $i$ infected cells. Then,

$$
w=\sum_{i=1}^{n} c_{i} b_{i}
$$

where

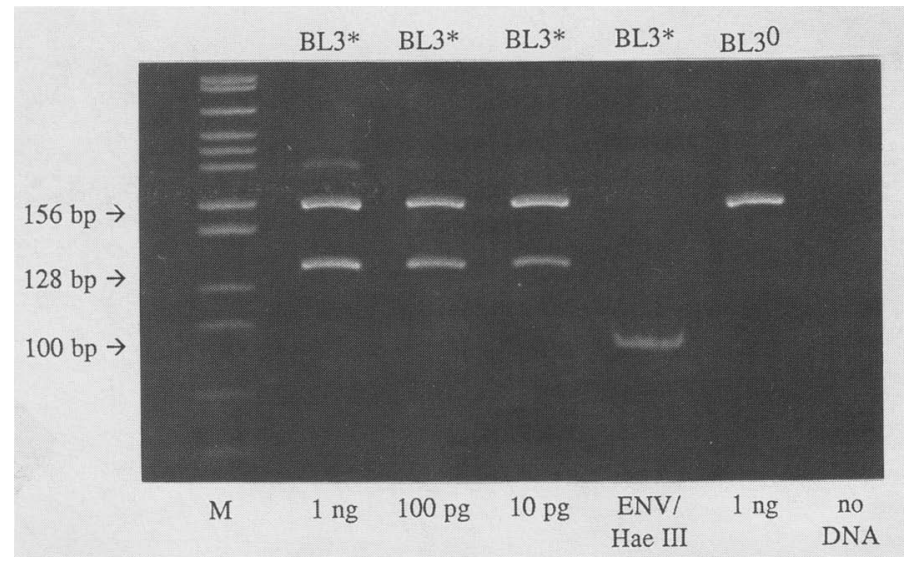

FIGURE 1 Simultaneous amplification of BLV ENV and bovine PRL from BLV-infected (BL3*) and uninfected control $\left(\mathrm{BL}^{\circ}\right.$ ) cell lines. (Lane 1) Marker (MspI digest of pBR322); (lane 2) $1 \mathrm{ng}$ of BL3* DNA as starting material; (lane 3) 100 pg of BL3* DNA; (lane 4) 10 pg of BL3* DNA; (lane 5) BLV ENV gene product cut with HaelII (100-bp fragment confirms product as BLV ENV); (lane 6) $1 \mathrm{ng}$ of $\mathrm{BL}^{\circ} \mathrm{DNA}$; (lane 7) no DNA.

$$
\begin{aligned}
& c_{i}=\left[1-(1-a)^{\mathrm{i}}\right] \\
& b_{i}=\{n ! /[i !(n-i) !]\} p^{i}(1-p)^{n-i}
\end{aligned}
$$

and where $i=$ number of infected cells, $n=$ number of cells per well, $a=$ operational sensitivity $(0<a \leqslant 1)$, and $p=$ the percentage of infected cells.

In equation (2), $(1-a)^{i}$ becomes zero and $c_{i}$ becomes 1 if $i$ is large, for example, when $i \geqslant k+1$. Note that $k+1$ must be $\leqslant n$. Therefore, if $i$ is large, equation (1) can be written as

$w=1-(1-p)^{n}-\sum_{i=1}^{k}(1-a)^{i} b_{i}$

The estimate for the percentage of infected cells, $\hat{\phi}$, can be obtained by substituting $\hat{w}$ for $w$ and solving equation 1 or 4 for $p$, but 4 is more efficient when wells contain large numbers of cells. When the number of cells per well is large, equations 1 and 4 are both high order polynomial functions of $p$ so that a numerical method is generally required to solve either equation. The standard deviation of $\beta$ is obtained using the formula $\sigma=[\operatorname{var} p]^{1 / 2}=\{[p(1-p)] / n t\}^{1 / 2}$. Given the percentage of infected cells and the number of cells per well, the probability for a given number of infected cells in a positive well can be obtained using equation 3 . Computer programs written to perform these calculations are available upon request.

\section{RESULTS}

\section{Amplification of BLV ENV and PRL from Isolated DNA}

The conditions necessary for the coamplification of cellular and viral DNAs were established using small quantities of DNA extracted from cell lines. Amplification of PRL (156 bp) and BLV ENV (128 bp) products was possible starting with as little as $10 \mathrm{pg}(\sim 1.5$ haploid genomes) of DNA isolated from the BL3* cell line (Fig. 1). Digestion of the BLV ENV PCR product with the restriction endonuclease HaellI produced the expected restriction fragment pattern $^{(13,22)}$, thus confirming its identity. The larger 100-bp restriction fragment was visualized after electrophoresis and ethidium bromide staining (Fig. 1). The 28-bp fragment was not easily distinguished owing to its small size. Reac- 


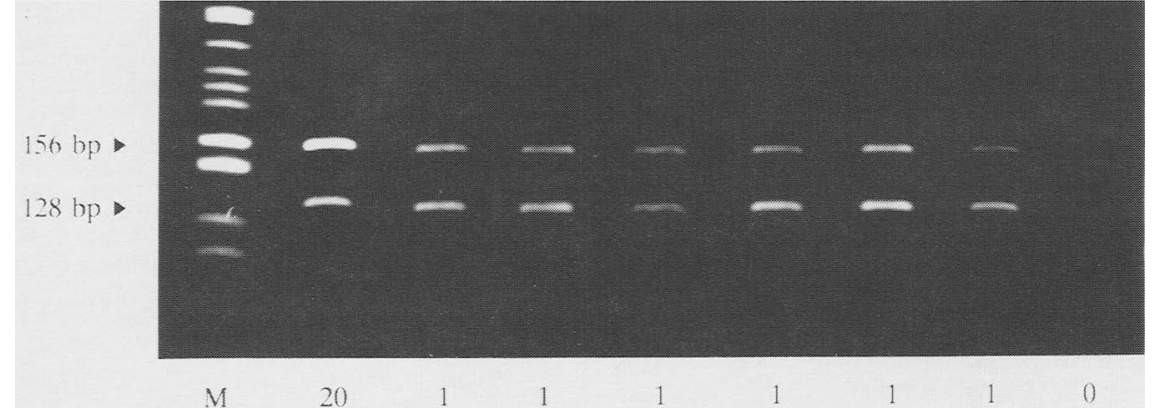

FIGURE 2 Simultaneous amplification of PRL and BLV ENV genes in individually sorted BL3* (Lane 1) MspI digest of pBR322; (lane 2) $20 \mathrm{BL} 3^{*}$; (lanes 3-8) 1 BL3*; (lane 9) no cell. Cells were sorted and amplified as indicated in Materials and Methods.

tions to which DNA from the uninfected $\mathrm{BL}^{\circ}$ cell line was added yielded only the 156-bp PRL product.

\section{Amplification of BLV ENV and PRL from Single BL3* Cells}

$\mathrm{BL}^{*}$ cells were sorted individually into wells of 96-well plates by flow cytometry. To determine the efficiency with which cellular and viral sequences could be detected, 65 individual $\mathrm{BL}^{*}$ cells were subjected to PCR (Fig. 2; Table 2). The PRL product was detected in $93.8 \%$ $(61 / 65)$ of the wells. Of these, $91.8 \%$ (56/ 61) contained both PRL and BLV ENV PCR products, thus providing an estimate of the operational sensitivity with which the two loci could be coamplified from single cells. In reactions containing PRL but not BLV ENV, the lack of the viral product could have been caused by a failure of amplification or by the presence of a small uninfected subpopulation of cells within the culture. By assuming that the lack of BLV ENV is the result of failed amplification rather than the absence of virus in the cell, our estimate of the operational sensitivity is more conservative. BLV ENV was not

TABLE 2 Operational Sensitivity for Simultaneous Amplification of BLV ENV and PRL from Individually Sorted BL3* Cells

\begin{tabular}{lllll}
\hline \multirow{2}{*}{$\begin{array}{l}\text { PCR product } \\
\text { detected }\end{array}$} & $1: 0$ & $1: 20$ & $1: 100$ & $1: 1000$ \\
\cline { 2 - 5 } & $93.8 \%(61 / 65)^{\mathrm{a}}$ & $97.7 \%(43 / 44)$ & $100 \%(44 / 44)$ & $100 \%(44 / 44)$ \\
PRL & $91.8 \%(56 / 61)^{\mathrm{b}}$ & $97.6 \%(42 / 43)$ & $90.9 \%(40 / 44)$ & $90.9 \%(40 / 44)$ \\
\hline
\end{tabular}

${ }^{a}$ Number in parenthesis within row is the fraction of the total number of wells receiving a single $B L 3^{*}$ that tested positive for PRL.

${ }^{b}$ Number in parenthesis within row is the fraction of the wells positive for PRL also testing positive for BLV ENV.

found in any reaction in the absence of PRL using either isolated DNA or cells as the starting template.

\section{Amplification of BLV ENV and PRL from Single Infected Cells among Uninfected Cells}

To establish the sensitivity for detection of single infected cells, a single BL3* cell was sorted into varying numbers of $B L 3^{\circ}$ cells. The BLV ENV sequence from a single BL3* cell was consistently identified in wells containing up to $10^{5} \mathrm{BL} 3^{\circ}$ cells in five replicate experiments (Fig. 3a). A single infected cell could be identified among as many as $1 \times 10^{6}$ uninfected cells, although the number of reactions in which product was identified was reduced (data not shown). To estimate the operational sensitivity for detecting viral sequences among larger cell numbers, a single $\mathrm{BL}^{*}$ cell was sorted into 44 wells containing 20,100 , or $1000 \mathrm{BL}^{\circ}$ cells. BLV ENV from a single BL3* was identified in $97.6 \%$ of reactions containing 20 uninfected cells and $90.9 \%$ of reactions containing 100 or 1000 uninfected cells (Table 2).

\section{Amplification of BLV ENV and PRL from Peripheral Blood B Cells}

To examine the utility of this method for the identification of viral sequences in BLV-infected animals, B cells from individual cows at different stages of BLV infection were sorted using a FITC-labeled antibody against surface immunoglobulin and subjected to PCR (Table 3). PRL was identified in $95.9 \%(71 / 74)$ of reactions performed using single cells from an animal with PL. Products from both loci were present in 49 of these 71 reactions, and it was estimated using equation 1 that $76.9 \pm 4.9 \%$ of $B$ cells contained BLV provirus. To verify this estimate of cellular infection, two B cells from this animal were sorted per well and $88 \%(34 / 43)$ of the reactions containing PRL were found to contain BLV ENV. Application of equation 1 gave an estimate of $73.3 \pm 4.6 \%$ infected B cells, not significantly different from the estimate obtained by testing single cells.

PRL was present in $92 \%(54 / 59)$ of wells into which a single $B$ cell from a seropositive non-PL animal was sorted. Only one of these 54 wells also yielded BLV ENV, providing an estimate of $\sim 2 \%$ infected B cells. To obtain a more accurate estimate of the percentage of infected cells in this animal, we increased the number of $B$ cells sorted into each well. When 20,100 , or 1000 B cells per well were tested, BLV ENV was identified in $2 \%, 6.5 \%$, and $26 \%$ of the wells containing PRL, respectively (Table 3 ). The results obtained from these experiments provided much lower estimates $(0.033 \%-0.115 \%)$ of BLV-infected B cells than that derived from the testing of single cells. For this set of experiments, $>97 \%$ and $92 \%$ of the positive reactions of BLV ENV obtained from 20 and 100 cells per well, respectively, and $\sim 70 \%$ of the positive reactions obtained from 1000 cells, are expected to be caused by a single infected cell in a well (Table 4). The remainder of the positive reactions would be caused by the presence of two or more infected cells in each well.

\section{DISCUSSION}

The identification of specific parameters that correlate with changes in disease status is important for monitoring and predicting disease progression, response to therapy, and for studying the dynamics of the host response to a pathogen. 


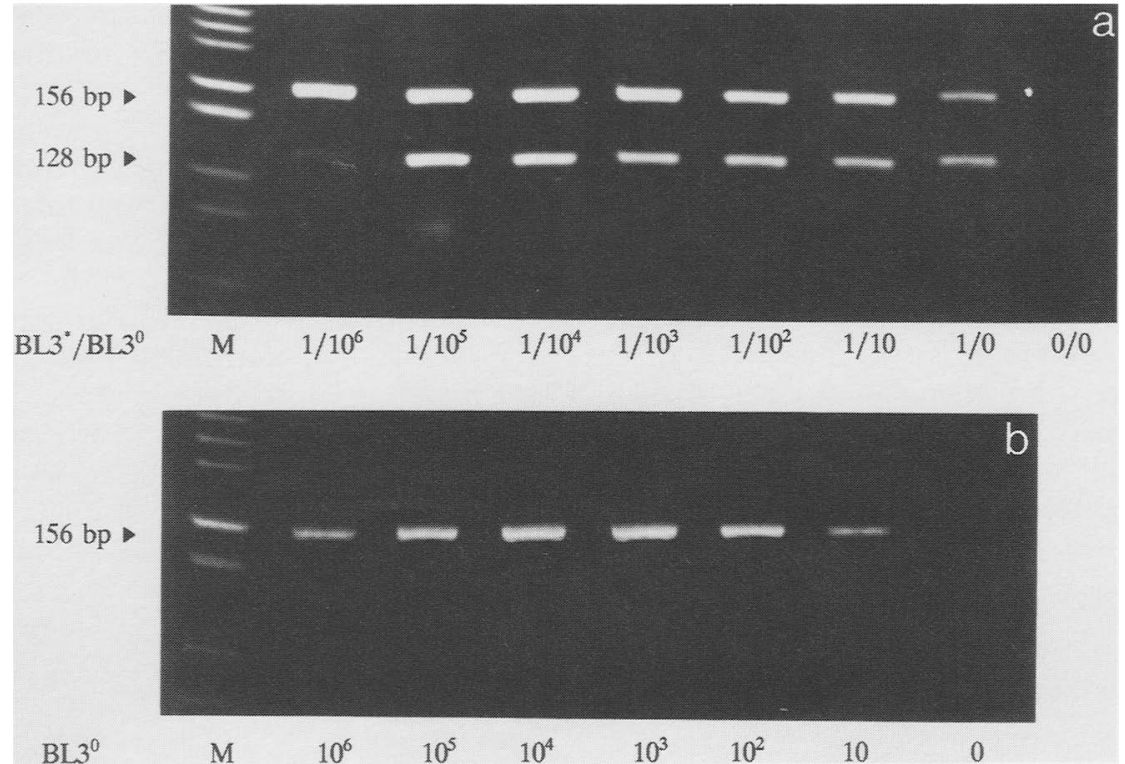

FIGURE 3 (a) Amplification of BLV ENV and PRL from individual BL3* sorted into varying numbers of $\mathrm{BL}^{\circ}$. Ratios given in lanes $2-8$ are numbers of $\mathrm{BL}^{\star}: \mathrm{BL}^{\circ}$. (Lane 1 ) MspI digest of

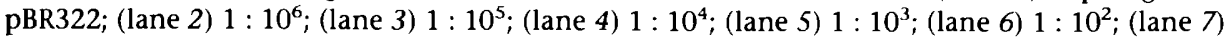
$1: 10$; (lane 8) $1: 0$; (lane 9) no cells. (b) Amplification of ENV and PRL from BL3 ${ }^{\circ}$. (Lane 11) MspI digest of pBR322; lanes $2-8$ contain $10^{6}, 10^{5}, 10^{4}, 10^{3}, 10^{2}, 10$, or $0 \mathrm{BL}^{\circ}$, respectively.
For example, a number of immunologic parameters have been shown to be useful in monitoring and predicting the development of AIDS and other conditions associated with HIV infection. ${ }^{(26,27)}$ The utility of many of these parameters is related to the deleterious effects of the virus on the $\mathrm{CD4}^{+} \mathrm{T}$ cell population in combination with increasing virus production as infection progresses. In comparison, BLV provirus is present in small copy numbers in each infected cell and infection in most peripheral blood cells is latent throughout the course of the disease. ${ }^{(28-30)}$ Therefore, the means by which progression of infection may be monitored are limited, increasing the value of a method that allows the direct identification of viral genes in host cells.

The separation of single cells for PCR was originally performed for the purpose of genetic analysis ${ }^{(31)}$ and gene mapping. ${ }^{(32)}$ Flow cytometry was recently introduced by Arnheim and co-workers to facilitate cell separation and expedite the examination of larger numbers of haploid cells. ${ }^{(17,18)}$ Data obtained in these studies were analyzed using maximum likelihood to estimate recombination frequencies, and models were validated by $\chi^{2}$ tests. These statistical methods were not, however, applicable to our
TABLE 3 Detection of PRL and BLV ENV in Sorted B Cells Isolated from Peripheral Blood of BLV-infected Cows with and without PL

\begin{tabular}{lccccc}
\hline $\begin{array}{l}\text { Disease } \\
\text { status }\end{array}$ & Cells/well & $\begin{array}{l}\text { Total cells } \\
\text { examined }\end{array}$ & $\begin{array}{l}\text { PRL }^{+} \\
\text {wells }\end{array}$ & $\begin{array}{l}\text { BLV ENV } \\
\text { wells }\end{array}$ & $\begin{array}{l}\text { Percent infected } \\
\text { B cells }^{\mathrm{a}}\end{array}$ \\
\hline $\mathrm{PL}^{+}$ & 1 & 71 & 71 & 49 & $76.9 \pm 4.9$ \\
& 2 & 86 & 43 & 38 & $73.3 \pm 4.6$ \\
$\mathrm{PL}^{-}$ & 1 & 54 & 54 & 1 & $2.02 \pm 1.91$ \\
& 20 & 900 & 45 & 1 & $0.115 \pm 0.113$ \\
& 100 & 4,600 & 46 & 3 & $0.075 \pm 0.040$ \\
& 1,000 & 46,000 & 46 & 12 & $0.033 \pm 0.009$ \\
\hline
\end{tabular}

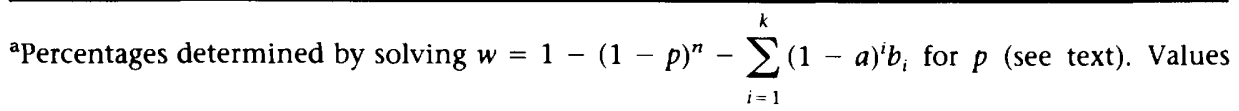
for operational sensitivity are the corresponding estimates in Table 2. studies. In this report we describe the adaptation of single-cell PCR methodology to detection of proviral DNA in individual lymphocytes. To determine the frequency of infected cells, a probabilistic statistical tool was developed that will permit the application of the method to several types of experimental problems for which the detection of low frequency genetic events is required.

We have shown that the percentage of cells containing virus can be reliably determined even when $<0.1 \%$ are infected. The use of flow cytometry provides precise control over the size of the population tested, with the option of testing as few as one or as many as $10^{3}$ cells per reaction. By adjusting the reaction volume and reagent concentrations, it should be possible to sort as many as $10^{4}$ cells in each well and test up to $10^{6}$ cells per plate. The method has the potential to estimate frequencies as low as $10^{-5}$. For other types of viral infections, individual cells that contain integrated or unintegrated viral DNA should be detected easily. Although labor intensive, the method can be scaled up for clinical monitoring using currently available technology. A person skilled in flow cytometry and cell sorting is needed, and precautions are required to eliminate sources of DNA contamination. ${ }^{(17)}$ From the time of blood sampling through sorting, PCR, and statistical analysis, it takes one skilled person using one 96-well PCR machine $\sim 3$ days to complete the analysis of one-half plate $(40-40,000$ cells, including controls).

When testing an animal with large numbers of infected cells (e.g., $\mathrm{PL}^{+}$), a single cell per reaction provides a reliable estimate of the percentage of circulating cells containing provirus. However, when the incidence of infected cells is low, as observed in the nonlymphocytotic animal, a large number of single-cell wells must be tested to obtain a reliable estimate of the percentage of cells containing provirus. The testing of multiple cells per well is more effective and possibly the only realistic method of obtaining estimates in such cases. Comparison of the variances of the estimates from experiments using 20,100, or 1000 cells per well provided a means of assessing the relative accuracy for each estimate. The low variance observed when testing 1000 cells per well (Table 3 ) supports this as the most accurate estimate of the percentage of circulating cells 
TABLE 4 Probabilities for the Number of Infected Peripheral Blood B Cells from a $\mathrm{PL}^{-}$Animal in Wells Positive for BLV ENV

\begin{tabular}{lccc}
\hline $\begin{array}{l}\text { Number of } \\
\text { infected } \\
\text { cells }\end{array}$ & \multicolumn{3}{c}{ Cells sorted per well } \\
\cline { 2 - 4 } & 20 & 100 & 1000 \\
\hline 1 & $0.9870^{\mathrm{a}}$ & 0.9591 & 0.8267 \\
2 & 0.0116 & 0.0388 & 0.1488 \\
3 & $<0.9\left(10^{-4}\right)$ & 0.0009 & 0.0165 \\
4 & $<0.5\left(10^{-6}\right)$ & $10^{-5}$ & 0.0014
\end{tabular}

${ }^{a}$ All probabilities determined from the formula $c_{i} b_{i} / w$. Values for $p$ are the corresponding estimates for the $\mathrm{PL}^{-}$animal in Table 3.

containing provirus. The estimates from experiments testing 20 and 100 cells per well have $95 \%$ confidence intervals that overlap with zero. For this nonlymphocytotic animal, the 20 and 100 cell experiments could yield a zero estimate if too few wells are tested even though infection is present.

The number of wells required to be tested to obtain an accurate estimate of the percentage of infected cells can be calculated on the basis of the number of cells sorted into each well, the limits for a confidence interval or the standard deviation, and a given percentage of infected cells. As shown in Table 5, an experiment testing single-cell wells for an animal with a low percentage of infected cells is generally unrealistic. A $1 \%$ infection rate would require the testing of 1585 wells to obtain a $95 \%$ confidence interval whose lower bound is $50 \%$ of the percentage of infected cells. Using multiple-cell wells, the number of wells required to be tested can be reduced. In general, when the number of cells per well $(n)$ is increased by a factor $(d)$ to an integer $(d n)$, then the number of wells required is $\sim 1 / d$ of that required for single-cell wells. For example, assuming a $0.01 \%$ infection rate, 17 wells would be required for 10,000 -cell wells, whereas $\sim 160,000$ wells would be required for single-cell wells (Table 5). It is important to note that the percentage of infected cells for multiple-cell wells could not be estimated if $100 \%$ of the wells have positive reactions. Therefore, the expected number of positive reactions must be taken into account when designing an experiment using multiple cells per well. This can be done in two steps. First, for an expected percentage of infected cells, the number of cells to be sorted per well and the number of wells to be tested should be determined. Second, the number of expected positive reactions should be obtained using $N \hat{w}$, where $N$ is the number of wells to be tested, and $\hat{w}$ is given by equation 1 or 4 . As shown in Table 5 , some designs are not allowed even though they require testing very

TABLE 5 Number of PCRs Required to Establish a Reliable Estimate of the Percentage of Infected Cells

\begin{tabular}{ccccccr}
\hline \multirow{2}{*}{$\begin{array}{c}\text { Number of cells } \\
\text { sorted per well }\end{array}$} & \multicolumn{6}{c}{ Percentage of cells containing BLV provirus } \\
\cline { 2 - 7 } & 10 & 5 & 1 & 0.1 & 0.01 & 0.001 \\
\hline 1 & 145 & 305 & 1585 & 15,985 & 159,985 & $1,599,985$ \\
& $(14)$ & $(14)$ & $(14)$ & $(14)$ & $(14)$ & $(14)$ \\
10 & 15 & 31 & 159 & 1,599 & 15,999 & 159,999 \\
& $(10)$ & $(11)$ & $(14)$ & $(14)$ & $(14)$ & $(14)$ \\
20 & 8 & 16 & 80 & 800 & 8,000 & 80,000 \\
& $(7)$ & $(10)$ & $(13)$ & $(14)$ & $(14)$ & $(14)$ \\
100 & 2 & 4 & 16 & 160 & 1,600 & 16,000 \\
& $(2)$ & $(4)$ & $(10)$ & $(14)$ & $(14)$ & $(14)$ \\
1,000 & 1 & 1 & 2 & 17 & 161 & 1,601 \\
& $(1)$ & $(1)$ & $(2)$ & $(10)$ & $(14)$ & $(14)$ \\
10,000 & 1 & 1 & 1 & 2 & 17 & 161 \\
& $(1)$ & $(1)$ & $(1)$ & $(2)$ & $(10)$ & $(14)$ \\
\hline
\end{tabular}

The number of wells required is based on a $95 \%$ confidence interval with a lower bound of $50 \%$ of the percentage of infected cells. The formula to obtain the number of PCR reaction wells is $N=I N T[1+16(1-p / n p)]$, where INT is an integer operator.

a(Top number) Number of PCR reaction wells required; (numbers in parentheses) the expected number of positive reactions according to the formula $N \hat{w}$ (see text). Designs beneath the step should not be used. few wells, because they would yield $100 \%$ positive reactions. By varying the number of cells tested per reaction, one can accurately quantitate the number of cells containing virus in individuals with large numbers of circulating infected cells as well as those with rare infected cells in the periphery.

In testing cells isolated from peripheral blood we demonstrated that $\sim 77 \%$ of circulating B lymphocytes ( $43 \%$ of the total leukocytes; data not shown) from an animal with PL and $\sim 0.04 \%$ of B cells $(0.01 \%$ of the total leukocytes; data not shown) from the BLV-infected nonlymphocytotic animal contained BLV provirus (Table 3 ). Using liquid hybridization, it was previously estimated that $25-40 \%$ of the circulating leukocytes in cattle with PL contain the BLV provirus ${ }^{(33)}$ and that integrated provirus is present in $<5 \%$ of leukocytes in nonlymphocytotic cows ( $5 \%$ was the lower limit for detection of viral DNA). ${ }^{(33)}$ The results that we obtained are consistent with these earlier estimates but demonstrate the far greater sensitivity and accuracy offered by combining flow cytometry with PCR for the quantitative detection of low numbers of infected cells. In our experiments, we elected to study B lymphocytes, but by utilizing fluorochrome-labeled monoclonal antibodies we will be able to separate and test a variety of cell types for the presence of virus.

The progression of $\mathrm{BLV}$ infection to the development of PL or lymphoid neoplasia has been known for some years to be influenced by genetic factors, ${ }^{(34-36)}$ and we have shown recently that resistance and susceptibility to the development of PL are closely associated with particular alleles of the bovine lymphocyte antigen (BoLA) complex, the bovine major histocompatibility system. ${ }^{(37)} \mathrm{Be}$ cause of these associations, we hypothesize that susceptibility and resistance to $\mathrm{PL}$ are related to the ability of the host to recognize and eliminate virus early in the course of infection. By determining the percentage of infected cells in animals of known BoLA haplotypes, our goal is to demonstrate an association between intrinsic components of the host immune system and events early in the course of infection that may be important determinants of resistance or susceptibility to disease. Single-cell analysis using PCR offers a powerful adjunctive tool for studying pathogenesis whenever the presence of specific genes or alter- 
ation in genetic sequences contributes to the development of disease, and may also prove applicable in the study of other infectious, neoplastic, or toxicologic diseases.

\section{ACKNOWLEDGMENTS}

We thank Ms. Julie Auger for her quality work with the flow cytometer. This work was supported in part by grant RO1 CA5914B awarded by the National Cancer Institute and by AG 92-37204-7956 from the U.S. Department of Agriculture, National Research Initiative.

\section{REFERENCES}

1. Kellogg, D.E. and S. Kwok. 1990. Detection of human immunodeficiency virus. In PCR protocols: A guide to methods and applications (ed. M.A. Innis, D.H. Gelfand, J.J. Sninsky, and T.J. White), pp. 337-347. Academic Press, San Diego, CA.

2. Saiki, R.K., S. Scharf, F. Faloona, K.B. Mullis, G.T. Horn, H.A. Erlich, and N. Arnheim. 1985. Enzymatic amplification of $\beta$-globin genomic sequences and restriction site analysis for diagnosis of sickle cell anemia. Science 230: 1350-1354.

3. Mullis, K., F. Faloona, S. Scharf, R. Saiki, G. Horn, and H. Erlich. 1986. Specific enzymatic amplification of DNA in vitro: The polymerase chain reaction. Cold Spring Harbor Symp. Quant. Biol. 51: 263273.

4. Ou, C.-Y., S. Kwok, S.W. Mitchell, D.H. Mack, J.J. Sninsky, J.W. Krebs, P. Feorino, D. Warfield, and G. Schochetman. 1988. DNA amplification for direct detection of HIV-1 in DNA of peripheral blood mononuclear cells. Science 239: 295-297.

5. Duggan, D.B., G.D. Ehrlich, F.P. Davey, S. Kwok, J.J. Sninsky, J. Goldberg, L. Baltrucki and B.J. Poiesz. 1988. HTLV-l-induced lymphoma mimicking Hodgkin's disease. Diagnosis by polymerase chain reaction amplification of specific HTLV-I sequences in tumor DNA. Blood 71: 1027-1032.

6. Bhagavati, S., G.D. Ehrlich, R.W. Kula, S. Kwok, J.J. Sninsky, V. Udani, and B.J. Poiesz. 1988. Detection of human T-cell lymphoma/leukemia virus type I DNA and antigen in spinal fluid and blood of patients with chronic progressive myelopathy. N. Engl. J. Med. 318: 1141-1147.

7. Naif, H.M., R.B. Brandon, R.C.W. Daniel and M.F. Lavin. 1990. Bovine leukaemia proviral DNA detection in cattle using the polymerase chain reaction. Vet. Microbiol. 25: 117-129.

8. Schatzl, H., L. Yakovleva, B. Lapin, D. Rose, L. Inzhiia, K. Gaedigk-Nitschko, F. Deinhardt, and K. von der Helm. 1992. Detection and characterization of T-cell leukemia virus-like proviral sequences in
PBL and tissues of baboons by PCR. Leukemia 6: 158S-161S.

9. Schnittman, S.M., M.C. Psallidopoulos, H.C. Lane, L. Thompson, M. Baseler, F. Massari, C.H. Fox, N.P. Salzman, and A.S. Fauci. 1989. The reservoir for HIV-1 in human peripheral blood is a $\mathrm{T}$ cell that maintains expression of CD4. Science 245: 305-308.

10. Simmonds, P., P. Balfe, J.F. Peutherer, C.A. Ludlam, J.O. Bishop, and A.J. Leigh Brown. 1990. Human immunodeficiency virus-infected individuals contain provirus in small numbers of peripheral mononuclear cells and at low copy numbers. $J$. Virol. 64: 864-872.

11. Kellogg, D.E., J.J. Sninsky, and S. Kwok. 1990. Quantitation of HIV-1 proviral DNA relative to cellular DNA by the polymerase chain reaction. Anal. Biochem. 189: 202-208.

12. Aoki, S., R. Yarchoan, R.V. Thomas, J.M. Pluda, K. Marczyk, S. Broder, and H. Mitsuya. 1990. Quantitative analysis of HIV-1 proviral DNA in peripheral blood mononuclear cells from patients with AIDS or ARC: Decrease of proviral DNA content following treatment with $2^{\prime}, 3^{\prime}$-dideoxyinosine (ddI). AIDS Res. Hum. Retroviruses 6: 1331-1339.

13. Sagata, N., T. Yasunaga, J. Tsuzuku-Kawamura, K. Ohishi, Y. Ogawa, and Y. Ikawa. 1985. Complete nucleotide sequence of the genome of bovine leukemia virus: Its evolutionary relationship to other retroviruses. Proc. Natl. Acad. Sci. 82: 677-681.

14. Kenyon, S.J. and C.E. Piper. 1977. Cellular basis of persistent lymphocytosis in cattle infected with bovine leukemia virus. Infect. Immunol. 16: 891-897.

15. Paul, P.S., K.A. Pomeroy, D.W. Johnson, C.C. Muscoplat, B.S. Handwerger, F.F. Soper, and D.K. Sorensen. 1977. Evidence for the replication of bovine leukemia virus in the B lymphocytes. Am. J. Vet. Res. 38: 873-876.

16. Burny, A., Y. Cleuter, R. Kettmann, M. Mammerickx, G. Marbaix, D. Portetelle, A. van den Broecke, L. Willems, and R. Thomas. 1988. Bovine leukemia: Facts and hypotheses derived from the study of an infectious cancer. Adv. Vet. Sci. Comp. Med. 32: 149-170.

17. Li, H., X. Cui, and N. Arnheim. 1991. Analysis of DNA sequence variation in single cells. Methods: Comp. Methods Enzymol. 2: 49-59.

18. Lewin, H.A., K. Schmitt, R. Hubert, M.J.T. van Eijk, and N. Arnheim. 1992. Close linkage between bovine prolactin and BoLA-DRB3 genes: Genetic mapping in cattle by single sperm typing. Genomics 13: $44-48$.

19. Romano, M.J., J.A. Stewart, and H.A. Lewin. 1989. Phenotypic characterization of bovine lymphoblastoid cell lines. Vet. Immunol. Immunopathol. 23: 293-307.
20. Lewin, H.A., M.-C. Wu, T.J. Nolan, and J.A. Stewart. 1988. Peripheral B lymphocyte percentage as an indicator of subclinical progression of bovine leukemia virus infection. J. Dainy Sci. 71: 2526-2534.

21. Mammerickx, M., R.J. Lorenz, O.C. Straub, W.J.C. Donnelly, J.C. Flensburg, G. Gentile, L.M. Markson, A.A. Ressang, and S.M. Taylor. 1978. Bovine hematology IIl. Comparative breed studies on the leukocyte parameters of several European cattle breeds as determined in the com. mon reference laboratory. Zentralbl. Veterinaermed. Reihe. B. 25: 257-267.

22. Rice, N.R., R.M. Stephens, D. Couez, J. Deschamps, R. Kettmann, A. Burny, and R.V. Gilden. 1984. The nucleotide sequence of the env gene and post-env region of bovine leukemia virus. Virology 138: 82-93.

23. Mamoun, R.Z., M. Morisson, N. Rebeyrotte, B. Busetta, D. Couez, R. Kettmann, M. Hospital, and B. Guillemain. 1990. Sequence variability of bovine leukemia virus env gene and its relevance to the structure and antigenicity of the glycoproteins. J. Virol. 64: 4180-4188.

24. Coulston, J., H. Naif, R. Brandon, S. Kumar, S. Khan, R.C.W. Daniel, and M.F. Lavin. 1990. Molecular cloning and sequencing of an Australian isolate of proviral bovine leukemia virus DNA: Comparison with other isolates. J. Gen. Virol. 71: 1737-1746.

25. Miller, S.A., D.D. Dykes, and H.F. Polesky. 1988. A simple salting out procedure for extracting DNA from human nucleated cells. Nucleic Acids Res. 16: 1215.

26. Yerly, S., E. Chamot, B. Hirschel, and L.H. Perrin. 1992. Quantitation of human immunodefiency virus provirus and circulating virus: Relationship with immunologic parameters. J. Infect. Dis. 166: 269276.

27. Krämer, A., R.J. Biggar, H. Hampl, R.M. Friedman, D. Fuchs, H. Wachter, and J.J. Goedert. 1992. Immunologic markers of progression to acquired immunodeficiency syndrome are time-dependent and illness-specific. Am. J. Epidemiol. 136: 7180.

28. Kettmann, R., G. Marbaix, Y. Cleuter, D. Portetelle, M. Mammerickx, and A. Burny. 1980. Genomic integration of bovine leukemia provirus and lack of viral RNA expression in the target cells of cattle with different responses to BLV infection. Leuk. Res. 4: 509-519.

29. Lagarias, D.M. and K. Radke. 1989. Transcriptional activation of bivine leukemia virus in blood cells from experimentally infected, asymptomatic sheep with latent infections. J. Virol. 63: 2099-2107.

30. Radke, K., T.J. Sigala, and D. Grossman. 1992. Transcription of bovine leukemia virus in peripheral blood cells obtained during early infection in vivo. Microb. Pathog. 12: 319-331. 
31. Li, H., U.B. Gyllensten, X. Cui, R.K. Saiki, H.A. Erlich, and N. Arnheim. 1988. Amplification and analysis of DNA sequences in single sperm and diploid cells. Nature 335: 414-417.

32. Cui, X., H. Li, T.M. Goradia, K. Lange, H.H. Kazazian Jr., D. Galas, and N. Arnheim. 1989. Single-sperm typing: Determination of genetic distance between the ${ }^{\mathrm{G}} \boldsymbol{\gamma}$-globin and parathyroid hormone loci by using the polymerase chain reaction and allele-specific oligomers. Proc. Natl. Acad. Sci. 86: 9389-9393.

33. Kettmann, R., Y. Cleuter, M. Mammerickx, M. Meunier-Rotival, G. Bernardi, A. Burny, and H. Chantrenne. 1980. Genomic integration of bovine leukemia provirus: Comparison of persistent lymphocytosis with lymph node tumor form of enzootic bovine leukosis. Proc. Natl. Acad. Sci. 77: 2577-2581.

34. Abt, D.A. 1968. Temporal aggregations of bovine leukosis in multiple-case herds. Bibl. Haematol. 31: 183-186.

35. Croshaw, J.E., D.A. Abt, R.R. Marshak, W.C.D. Hare, and J. Switzer. 1963. Pedigree studies in bovine lymphosarcoma. Ann. N.Y. Acad. Sci. 108: 1193-1202.

36. Lewin, H.A. and D. Bernoco. 1986. Evidence for BoLA-linked resistance and susceptibility to subclinical progression of bovine leukaemia virus infection. Anim. Genet. 17: 197-207.

37. Van Eijk, M.J.T., J.A. Stewart, J.E. Beever, R.L. Fernando, and H.A. Lewin. 1992. Development of persistent lymphocytosis in cattle is closely associated with BoLADRB2. Immunogenetics 37: 64-68.

38. Sasavage, N.L., J.H. Nilson, S. Horowitz, and F.M. Rottman. 1982. Nucleotide sequence of bovine prolactin messenger RNA. J. Biol. Chem. 257: 678-681. 


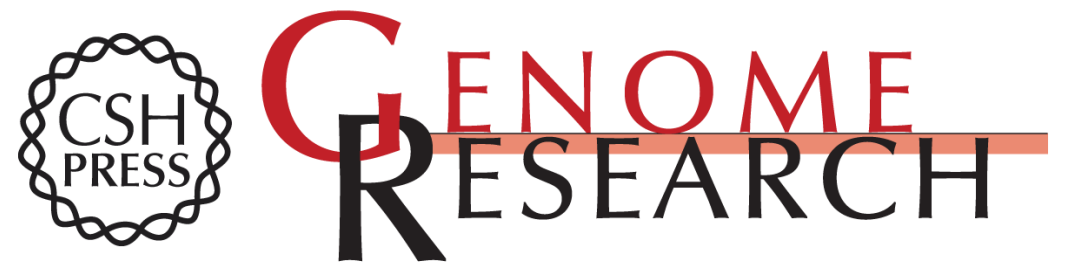

\section{Detection of bovine leukemia virus proviral DNA in individual cells.}

M L Mirsky, Y Da and H A Lewin

Genome Res. 1993 2: 333-340

Access the most recent version at doi:10.1101/gr.2.4.333

References This article cites 37 articles, 13 of which can be accessed free at:

http://genome.cshlp.org/content/2/4/333.full.html\#ref-list-1

\section{License}

Email Alerting Receive free email alerts when new articles cite this article - sign up in the box at the Service top right corner of the article or click here.

\section{Affordable, Accurate Sequencing.}

To subscribe to Genome Research go to:

https://genome.cshlp.org/subscriptions 